UDC $159.922 .76-053.4-056.262$

DOI: $10.26565 / 2410-1249-2020-13-08$

\title{
THE BLIND CHILD DURING EARLY CHILDHOOD (0-3 YEARS) AND THE EDUCATIONAL INTERVENTION
}

\author{
Dimitris Argiropoulos \\ Ph.D. in Pedagogy, University of Parma, Parma, Italy \\ E-mail: dimitris.argiropoulos@unipr.it; https://orcid.org/0000-0001-5373-5893
}

\begin{abstract}
This article aims at approaching the role of education in accompanying the growth of blind children from early childhood. Blindness has several impacts on the juridical, medical, social and educational plans, which concur in defining the blind person, together with the individual features and cultural contexts in which the person lives. Here we will focus on the first years of life, to understand the most crucial factors in the development of the blind child from an educational perspective. The article puts forward a multidisciplinary educational method, where an equipe should take care of the blind child and elaborate objectives together with the family. Communication among adults observing the child in different life contexts is particularly important, allowing timely compensation interventions. An attitude of continuous observation and mediation with the family allows an authentic childcentered approach.
\end{abstract}

KEYWORDS: visual impairment, blindness, visus diagnostics, early educational intervention, mediation, parents' education. family activation

1. The blind child and the early educational intervention orientation.

The early intervention is aimed to visually impaired children in pre-school age, involves subjects affected by very different eye pathologies, which can be resumed by the macro-categories that range from blindness to low vision. Visual pathologies can be associated to other disabilities, but we decided to focus the topic of the present work to the sole total blindness condition experienced by children between 0 and 3 years old.

The encounter with a blind child and his family with educators that work on early intervention develops around individual meeting moments during which specialized activities are applied in order to aim to reduce developmental delays, which are a secondary effects of the visual impairment, and also promote the very development of the blind child.

The main goal of the developmental diagnosis focused on the intervention resides on elicit indication from the course and from the peculiarities of the development, thus allowing to propose an intervention aimed to growth and a adequate advice for parents.

"To promote development means to give directions, adequate to the child's developments times, that can be used by parents during everyday life; those indications, given for the early intervention, has to take into account the individual abilities and peculiarities of the child and has to integrate family's specific structure." (Brambring, 1999, p. 13).

About this, Brambring explains that the scientific foundation of early intervention by spotting the connection that has to be created, unavoidably, with the life context of the child; it is, indeed, necessary to build a bridge through which move, transfer and make available special knowledge in everybody's context.

"One cannot think to propose to every child a similar program or training since this would not reflect the concept of an early intervention based on the child development and psychology. The developmental psychology theory is based on the fact that development does not happen with the isolated acquisition of independent skills, but throgh complex relations connected to reality. The child's skills and social influences of the environment interact in a systemic interchange, mutually affecting one another, (Brambring, 1999, p. 13).

The educational act cannot be attributed only to a "philanthropic love" feeling", neither can be justified 
with the strict practice of a special profession, neither, of course, terminate into the unconscious reiteration of personal models. In every intentional relationship, the underlying educational act must be explicit and conducted with responsibility. Referring to the function and roles of educators as special profession Andrea Canevaro, clearly states the difficulties of dialogues among the activities of special contest with those open to everyone.

In the educational activity aimed to the blind child, the dichotomy between different systems and the consequences that said dichotomy has on family,children and on the same educators, are in a certain manner evident.

The lack of dialogue and of unity of intents among different contexts gives a broken perception of the child to the family, which is living, since when the child was born, in an uncertain dimension in which every reference is under discussion. The medical and health indication in the first instance, the rehabilitative and typhlological then, play the priority role of interest for the parents in that order of importance. The family investment is heavy as far as the need to reduce/solve the child problem. Educational aspects and of "normal" life of the child are perceived as less important, of secondary importance and understood as subordinate to any technical or specialized indication. Various systems, of intervention, are usually unable to integrate due to the lack of resources and dialogue tools. Jealousy forms among professional special staff in respect to their own practices and the lack of a far sighted standpoint make them think, often, that their way is exhaustive and sufficient. The results in these cases are ineffective and the consequent waste of resources is huge. Those intervention that potentially could generate a change towards the improvement of blind children and their families life quality, often loose consistency and fail.

Thus, the need of an organic reflection on the role of education as far as the interventions that aim to promote the blind child's growth since the very early childhood. The encounter with a blind child and his family with educators that work on early intervention develops around individual meeting moments during which specialized activities are applied in order to aim to reduce developmental delays, which are a secondary effects of the visual impairment, and also promote the very development of the blind child..

Working with children always means to start with the family and involve it; the contribution of Andrea Canevaro is, in that sense, paramount:

"working with parents: one of the most important activity ... the challenge is also that: extract form one's personal professional organization the adequate tools, that may need adaptation, but also in some cases ready to use, as far as the interchange possibility and support to parental figures are concerned». (Canevaro, 2016, p. 113).

The early intervention is aimed to visually impaired children in pre-school age, involves subjects affected by very different eye pathologies, which can be resumed by the macro-categories that range from blindness to low vision. Visual pathologies can be associated to other disabilities, but we decided to focus the topic of the present work to the sole total blindness condition experienced by children between 0 and 3 years old.

The early intervention, for its own nature, look at the child from a standpoint of continuous observation and of mediation towards the family, as well written by Michael Brambring:

"The main goal of the developmental diagnosis focused on the intervention resides on elicit indication from the course and from the peculiarities of the development, thus allowing to propose an intervention aimed to growth and a adequate advice for parents. (Brambring, 1999, p. 13). To promote development means to give directions, adequate to the child's developments times, that can be used by parents during everyday life; those indications, given for the early intervention, has to take into account the individual abilities and peculiarities of the child and has to integrate family's specific structure."

The multidisciplinary structure of the educational work carried on by a team guide a shared taking care of the blind child and the clear individuation of goals together with the family. Moreover, the communication between adults, who observe the child in different life contexts, allows the early activation of possible compensation practices and of the involved services. 
The multidisciplinary paths, specific to the special professional practice, should always necessarily involve the educators.

Consultancy requests arise from the need to solve the educational problem that educators, but also parents, encounter in referring to a blind child. Adults, who do not have specific training, encounter difficulties in adapting educational practices to the blind child since the lack of sight characterizes in a peculiar manner the way and the times in which the blind child realizes the learning. There is a need to individualize the proposals starting from considering the limits that blindness imposes without precluding the blind child from the possibility of achieving the same growth objectives as sighted peers.

About this, Brambring explains that the scientific foundation of early intervention by spotting the connection that has to be created, unavoidably, with the life context of the child; it is, indeed, necessary to build a bridge through which move, transfer and make available special knowledge in everybody's context:

"One cannot think to propose to every child a similar program or training since this would not reflect the concept of an early intervention based on the child development and psychology. The developmental psychology theory is based on the fact that development does not happen with the isolated acquisition of independent skills, but through complex relations connected to reality. The child 's skills and social influences of the environment interact in a systemic interchange, mutually affecting one another" (Brambring, 1999, p. 13).

The actors involved in the early intervention come from different study background, health, educational, technical, with a specific preparation in the typhlological field. The set of professions, experts, methods, theories and aids designed to reduce the impact of visual impairment on children's lives is infinite and is destined to grow and to undergo criticism and reinterpretations; the constant that unites each teacher and teaching is the means that they use, in other words, education (Gatty, 2010, p. 28). Any operator who carries out his professional activity with a child must be aware of his educational responsibility and consider it an essential resource to be put in communication with the resources that are proper to other professions, including that of the educational sciences.

The multidisciplinary and multimodal approach to work is the result of a research tradition coming from the European Countries which dictate the inclusion of children with sensory disabilities in Special Schools. The distance that often separate the world of specialized work from that of the educational inclusive institution is not possible in our country, if one doesn't want to go against the application of the "integration bill".

On the opposite side from the dangerous specialized lost of track there is the, equally dangerous, inadequate educational practice which endanger the child development, the integration and the work of educators. Jean Gatty describes the ultimate aim of education as the child's conquer of one self free dominance (Gatty, 2010, p. 36) and that very goal resides at the base of every profession that aims to promote the person development and his autodetermination.

\section{Definition and Laws}

The visually impaired child is, first and foremost a child that characterizes in the specification of "visually impaired", but does not identify in it. Visual impairment is an important aspect due to the effects it has on the development of the child, as we will see in the rest of the work, but does not substantiate the being of the person. Each child is unique and is a complex (Greenspan, 1992, p. 21) being who, at the moment of his coming into the world, enters into a relationship with others and with objects. The sensory impairment is therefore to be understood as one of the elements of uniqueness among others that describes the child and that is shown in the ways and times in which his relationships with the world take place.

The terms of childhood and disability refer to opposing representations which, in the first instance, appear in conflict with each other. Pregnancy, birth and childhood bring to mind a moment in man's life characterized by potential, the newborn is conceived in the dimension of the possibilities in which everything can do, everything can become (Debray, 2009, p. 31). The life of the blind child 
begins with a deficit, with a deficiency considered an a priori limit that operates indiscriminately with respect to the potential of his being born. The start to life of the newborn is disadvantaged and this idea permeates the thoughts of adults from the moment of the first diagnosis. The typhlologist Enrico Ceppi in 1981 described the emotional consequences that the new of blindness arises in the children's parents.

"The suffering and bewilderment that inevitably accompany the first manifestation of the minority, give way to a state of resigned prostration and are replaced by a frantic search for solutions sometimes impossible and miraculous" (Ceppi, 1981, p. 64).

Similar feelings can affect all adults who are confronted with a blind child, including educators and professionals (Tesio, 2000, p. 18). Awareness of the child's blindness creates a negative perception of loss that risks materializing in scenarios in which the reduction of the disadvantage appears almost impossible.

Tesio's contribution from an interesting volume on the psychological aspects experienced by parents of disabled children describes the state of mourning and disarmament that a mother and father live

"With the disabled child the expected child dies, but remains a body whose psychological growth is very difficult, because it cannot be represented in the parent's mind".

This experience does not belong to the professional and the internal conflict that he can experience between the positive image of childhood and the negative image of disability arises from personal representations, from stereotypes and any possible prejudices that guide his ideas and therefore actions. (Hoyuelos, 2014, p. 25). Any possible conflict must be addressed and solved so that it is possible to give the child a real and positive contribution to its development and adequate support to the family. The representation of the blind child based on his potential and not on his shortcomings is the fundamental prerequisite for preventing one of the most typical consequences of an education that focuses on the limits of the child and not on its potential and which Enrico Ceppi describes:

"The visual impairment is unconsciously rejected and the child is placed in a situation of dutiful acceptance: thus, the overprotective attitudes are born which can organize themselves in exacerbated forms of physical protection of the little blind child. Physical protection inhibits any form of movement, truncates the child's residual possibilities of establishing sporadic contacts with the world around him, increasingly ties to early childhood life forms, mortifying his own need to grow, to know, to express himself towards the environment. The child's requests are met without giving the possibility of experimenting, without allowing him the emergence of an order and discipline indispensable for the healthy progress of the acquisition of physical and psychic control of his own organic life" (Ceppi, 1981, p. 65).

The author refers to parents, but an overprotective approach can also be implemented by adults who take care of the child in different educational contexts. The idea of the child with rights and a citizen of the world also applies to the blind child, he can and must be put in the conditions for self-determination. This objective can only be pursued on condition that the adults involved in the education of the child investigate the quality of the relationship they are capable of establishing. The prerequisite, and we particularly want to point it out, is explicitly to affirm that "personal development is achieved only in the relationship with others" (Sani, 2013, p. 44) and this relationship must be sized starting from the representations that the adult has of the child, of the disabled child and his family. To this end, it is useful to know the different aspects that concern the condition of visual impairment and that are necessary to develop a critical awareness of one's educational role in the life of the blind child. Giancarlo Accorsini's contribution exemplifies the importance of a conscious educational work, towards a blind child, in this passage: «The blind, it is clear, must live among the sighted and they can only do so through an assiduous, intelligent adaptation work which is essentially determined by the type of education they receive, which must be not casual and approximate, but intentional and specific» (Accorsini, 1988, p. 32).

A country's legislation encompasses the cultural and regulatory principles of society and the historical events experienced by the people who produced it. 
The reference to the legislation in force in Italy makes it possible to univocally define the fundamental terms necessary to develop the present work.

Visual impairment is a condition of sensory impairment that the Italian State classifies and quantifies with the Law, n. 138 of April 3rd, 2001 "Classification and quantification of visual impairments and rules on eye examination" (Law April, 2001). The present work refers to the conditions of visual impairment defined by the law in the Art. 2.1 and called total blind. The classification is reported in its entirety for completeness and since it provides important indications regarding the intentions of the legislator and the socio-political orientations that led to this law.

\section{Art. 1. (Field of application).}

1. This law defines the various forms of visual impairment worthy of legal recognition, in order to adequately regulate the quantification of low vision and blindness according to the parameters accepted by international eye medicine. This classification, of a technical-scientific nature, does not change the current legislation on economic and social benefits in the care sector.

Art. 2. 1. For the purposes of this law, total blinds are defined as such:

a) those who are affected by total lack of vision in both eyes;

b) those who have the mere perception of shadow and light or of the motion of the hand in both eyes or in the best eye;

c) those whose binocular perimeter residue is less than 3 percent.

Art. 3. 1. Partial blinds are defined as such:

a) those who have a visual residue not exceeding $1 / 20$ in both eyes or in the best eye, even with any possible correction;

b) those whose binocular perimeter residue is less than 10 percent.

Art. 4. 1. Serious visually impaired are defined as such:

a) those who have a visual residue not exceeding $1 / 10$ in both eyes or in the best eye, even with any possible correction;

b) those whose binocular perimeter residue is less than 30 percent.
Art. 5. 1. For the purposes of the present law, the following are defined as medium - severe visually impaired:

a) those who have a visual residue not exceeding $2 / 10$ in both eyes or in the best eye, even with any possible correction;

b) those whose binocular perimeter residue is less than 50 percent.

Art. 6. 1. Slightly impaired are defined as such:

a) those who have a visual residue not exceeding $3 / 10$ in both eyes or in the best eye, even with any possible correction;

b) those whose binocular perimeter residue is less than 60 percent (Law April, 2001).

According to the World Health Organization (WHO) a subject is blind when the correct visual acuity in the best eye is less than $1 / 20$, while he is partially sighted when it is comprised between $3 / 10$ and $1 / 20$. This distinction dates back to about twenty years ago, in the International Statistical Classification of Diseases and Related Health Problems (ICD -10) five categories have been defined (International Agency, 2010):

The first and second concern the visually impaired:

- $\quad 1^{\circ}$ cat. $=$ visus $3 / 10-1 / 10$;

- $\quad 2^{\circ}$ cat. $=$ visus $1 / 10-1 / 20$.

The other three categories concern, instead, the

\section{blind subject:}

- $\quad 3^{\circ}$ cat. $=$ visus $1 / 20-1 / 100$;

- $\quad 4^{\circ}$ cat. $=$ visus $1 / 100-$ For Far (F.F.);

- $5^{\circ}$ cat. $=$ visus off.

The visus corresponds to visual acuity, that is, to the level of definition with which the eye sees an image (International Agency, 2012) and also in Italy, up to the law 138 of 2001, the measurement of the visus was the only useful parameter to define the degree of visual impairment. Even today, therefore, there is no uniformity of classification at an international level and even within the same country it is not difficult to find different solutions in addressing the topic related to low vision. Its correct definition has an important weight in the rehabilitation, insurance and medico-legal fields (Cruciani, 2005, p. 14).

Visual acuity is one of the factors for establishing an individual's visual ability, but is to be considered 
incomplete if taken individually; in fact, in looking at an image the eye also perceives what is around it through peripheral vision, also called visual field. The damage of the visual field is as disabling as the reduction of visual acuity, in fact while a reduction of the visus compromises the ability to recognize a face or to read, a damage to the peripheral vision can affect the ability of an individual to move and in some cases prevent him from even moving one step (Agenzia Internazionale, 2017).

The vision, and the mechanism of vision in its entirety, is a complex system whose realization requires the interrelation between different structures such as the eye, the central nervous system and the peripheral nervous system. [...] Defining, in fact, the vision as what allows you to see is extremely reductive, since the perfect correlation of all the structures involved in the mechanism of the vision allows both to achieve three-dimensionality and therefore to orientate in space, and to perceive the movement and therefore to modulate the movements of the body according to the needs (Società Oftalmologica, 2017).

The merit of the Law 138 of 2001 lies in expanding the scope of low vision and the application of the rights recognized to people with visual disabilities. The law 1138 suggests the attention that in our country the scientific community, the institutions and the trade associations give to people with vision impairments. The article published in 2006 on Social Ophthalmology journal "Classification of low vision" contains an interesting and authoritative comment on law no. 138/01 which the authors define:

"Undoubtedly a good law in that it fills a regulatory gap: visually impaired people obtain official recognition of existence" (Cruciani, 2005, p. 17).

The present work takes into account total blindness in both eyes in the young child, a condition in most cases congenital, i.e. present from birth, which can be caused by genetic pathologies, malformations or infections that occurred or matured during pregnancy or childbirth (Centofanti, 2017). In very rare cases they are of traumatic origin and therefore acquired. A further and important cause that can determine total blindness in the baby is Retinopathy of prematurity (ROP). ROP is a retinal disease that occurs in premature babies and usually occurs in both eyes, although it can have different degrees of severity. Low body weight at birth is a risk factor: in fact, a baby born with a weight less than 1250 grams is more likely to develop a mediumsevere form of ROP. Retinopathy of prematurity is caused by the abrupt hyperoxia condition in which the infant finds himself that compromises normal retinal vascularization (Rop Italia, 2017).

In obstetrics, a newborn child is defined as premature if born before completing the 37 th week of pregnancy, that is, before days have passed since the last maternal menstruation (Agenzia Internazionale, 2007). The most serious cases of ROP generally correspond to a high prematurity (23rd week of pregnancy) and determine the total blindness of the newborn: «Based on the duration of the pregnancy, a birth is defined as: strongly premature (before the 32nd week), premature (between the 32nd and the 36th week), on term (between the 37th and the 42nd week), post-term after the 42nd week» (Glossario ISTAT, 2013).

The website of the Ministry of Health, on the occasion of the world day of sight in October 12th, 2007 , reports a summary indication of childhood eye diseases that affect children today in very early childhood and in which the ROP is the first cause:

the main causes of severe visual impairment avoidable in developmental age are retinopathy of prematurity (ROP), congenital cataract and opacities of the cornea. In high-income countries such as Italy the most common causes are visual impairment due to brain disorders (CVI - Cerebral Visual Impairment), congenital malformations of the optic nerve and hereditary retinal diseases. In particular, CVI alone can occur in 2 out of 1000 children (Ministero della Salute, 2017).

CVI or Visual Disturbance of Central Origin represents one of the major causes of low vision in developmental age, in relation to the increased survival in the western world of severely premature subjects and / or with severe neonatal suffering. The anatomical structures involved in this type of damage are different and internal to the central nervous system (Bianchi, 2009, p. 9). Here we do 
not enter into the merits of the individual pathologies given the amplitude of the subject and considering the specific medical competence that it would be necessary to possess to face them, also they are not of strict interest for the purpose of the thesis work. The International Agency for the Prevention of Blindness (IAPB) offers useful information sheets on the main eye diseases on its website (Agenzia Internazionale, 2017) which are easy to consult.

\section{The concept of disability and visual impairment}

The concept of disability has long been discussed by the national and international scientific community due to its medical, health, political and social implications, undergoing several revisions over time. The need for continuous terminological redefinition reflects the complexity of the concept of disability due to its implications in the various systems of social life. Words as signs are closely related to the conceptual thinking of people and underlie shared collective symbolic representations. The intentional character of words expresses the culture of a society and the attitude it takes towards specific situations (Tartabini, 2006, p. 123).

A path that allows us to recall the formal and substantial changes in the concept of disability is highlighted in the research conducted by the World Health Organization (WHO) in recent years. In 1980 WHO published the International classification of impairments, disabilities and handicaps (ICIDH) which, with the subsequent modifications added in thw 1999 ICIDH, is proposed as an appendix to the International Classification of Diseases (ICD). The ICD is a classification system that incorporates diseases, disorders and injuries in a biomedical perspective, while the ICIDH tries to grasp what can happen in association to and as a consequence of a disease, using a biopsychosocial approach. ICIDH is the classification of the consequences of diseases that considers the deficit and the etiology of the disorders (Buono, 2003, p. 126). The term deficit means lack and a deficit-oriented approach has the direct focus on "what is not there" compared to an ideal canon on the negative aspects of the situation that an individual experiences. In this perspective, in the ICIDH there are definitions of the terms Impairment, Disability and Handicap within the document:

Impairment Any loss or abnormality affecting a psychological, physiological or anatomical function is characterized by material losses or abnormalities that can be transient or permanent and include the existence or occurrence of anomalies, defects or losses affecting the limbs, tissues or other body structures, including the mental function system. The impairment represents the externalization of a pathological state and in principle, reflects the disorders shown at the organ level.

Disability means any limitation or loss (resulting from impairment) of the ability to perform an activity in the manner or extent considered normal for a human being. Disability is characterized by deviations, in excess or in defect, in the execution of tasks and in the expression of behaviors with respect to what would normally be expected. It can be transitory or permanent and be reversible or irreversible, progressive or regressive.

Handicap in the context of health-related events, is the condition of disadvantage resulting from an impairment or a disability that in a given person limits or prevents the fulfillment of his normal role in relation to age, gender and socio-cultural factors. The handicap concerns the meaning assumed by an individual situation or experience when it deviates from normality. It is characterized by the discrepancy between the efficiency or state of the subject and the expectations of efficiency and status of both the same subject and the particular group to which he belongs. It therefore represents the socialization of an impairment or a disability and as such reflects the cultural, social, economic and environmental consequences that derive from the presence of the impairment and disability. The disadvantage comes from the decrease or loss of the ability to comply with the expectations or rules specific to the context in which the person lives. The handicap therefore manifests itself in the presence of an impairment of the ability to support what can be called survival functions (Buono, 2003, p. 124).

The approach related to the affections determined by the disease proposed by ICIDH is represented by the sequence disease or disturbance - impairment - 
disability - handicap and does not adequately underline the importance of the social and environmental context in the processes of compromise. The revision of the ICIDH led to the publication of the ICIDH-2 in 1997 in which the terms Impairment, Disability and Handicap were replaced respectively with the expressions of Functions and Body Structure; Activities that indicate whatever a person does at any level of complexity; Participation that concerns the interaction between impairments, activities and contextual factors. The ICDH-2 was revised and then approved by the WHO in May 2001 in the form of the International Classification of Functioning, Disability and Health (ICF). The classification proposed in the ICF detects the elements that mainly serve to prevent or identify the person's needs and not to detect a pathological state. This point of view allows the description of the functioning processes of health and disabilities. From the detection of deficits, that is, of the only negative aspects present in conditions of disability, we moved on to a detection system that uses neutral terms, in fact applicable to any individual. The ICF, since interested in the functioning, proposes a grid that considers the effects of disability and not its causes by identifying two main parameters: Functions and Body Structures that concern the components of health, Activities and Participation. The Activity consists in the execution of a task or an action by an individual, the Participation indicates the involvement in a life situation. Environmental factors become a fundamental element in the assessment of disability: in fact, the negative aspects, the deficits, are defined as Activity Limitations which result in the difficulties that an individual may encounter in carrying out activities (Buono, 2003, p. 126) and Restrictions on Participation that concern the problems that an individual can experiment in his involvement in life situations (Buono, 2003, p. 126). The ICF includes the Environmental and Personal Factors which, in relation to the health condition of an individual, determine its functioning. The classification does not deal with the diagnosis, but considers the social context as the element that determines the severity of the impairment or disability. In this sense, it is not the classification of individuals that is achieved, but the description of the situation that each individual can experience within a series of domains of health and the states related to it:

"recognizes that disability does not concern a separate category of people, but can affect any person, since anyone can be in a health condition that in an unfavorable environmental context causes disability" (Menichini, 2003).

A significant contribution that explains the perspective of the concept of disability proposed by the ICF is that of Andrea Canevaro who writes

"Limitations (disabilities) are related to contexts. Disability as a permanent datum does not exist: there is a certain disability and it is a process. So the disadvantage could prove more relevant in one context, less or even disappear in another" (Canevaro, 2016, p. 19).

The ICF is complementary to the ICD in the sense that its application follows the specific diagnostic procedures that each individual case requires. The ICF is apt to be used by health agencies of social and educational policy services by providing a standardization of language that favors communication between the various users.

In Italy there has been a process of reinterpretation of the condition of disability experienced by individuals in terms of recognition of rights and socio-health and educational assistance. In the approval of some laws, important historical junctions can be identified that have led our country to integrate disabled people into normal life contexts. Starting from the Laws 180 (Normattiva, 1978) of 1978, which saw the closure of psychiatric hospitals, and 517 (Normattiva, 1977) of 1977 which opened schools for the disabled by closing special schools, promoting integration and creating the figure of the support teacher, we came to the law 104 (Gazzetta Ufficiale, 1992) of 1992 which is the State framework Law that supports the rights of disabled people throughout the life cycle, implementing the tools to encourage school, social and work integration.

In Art. 3.1 of the law 104 of 1992, which still shows the term handicap later removed in the WHO document of 2001 since became discriminatory in current use in different countries, already placed the social and integration aspect of the person's life as 
central elements in the condition of disability (Canevaro, 2016, p. 121):

"A handicapped person is a person who has a stabilized or progressive physical, psychic or sensory impairment, which is the cause of learning, relationships or work integration difficulties and such as to determine a process of social disadvantage or marginalization" (Gazzetta ufficiale, 1992).

The article 1 defines the purposes of the Law 104 of 1992 which proposes an innovative approach compared to other countries and anticipates the international orientation: it, in fact, takes into consideration the functional aspects and family relationships related to disability:

The Republic:

a) guarantees full respect for human dignity and the rights of freedom and autonomy of the handicapped person and promotes their full integration into the family, school, work and society;

b) prevents and removes the invalidating conditions that prevent the development of the human person, the achievement of the maximum possible autonomy and the participation of the handicapped person in the life of the community, as well as the realization of civil, political and property rights;

c) pursues the functional and social recovery of the person affected by physical, mental and sensory impairments and ensures the services for the prevention, treatment and rehabilitation of the disabled, as well as the legal and economic protection of the disabled person;

d) arranges interventions aimed at overcoming states of exclusion and social exclusion of the disabled person (Gazzetta ufficiale, 1992).

The decree 66 (Gazzetta ufficiale, 1992) of April, 13th 2017, referring to the Good School (Gazzetta ufficiale, 2015) is the last provision regarding the Rules for the promotion of school inclusion of students with disabilities. The decree makes changes to the law 104 of 1992 explicitly including in Art. 5 (Gazzetta ufficiale, 2017) the ICF as regards the Individualized Educational Plan (IEP). This figure reflects the need for Italy to adapt to international provisions in order to comply with the parameters that allow the improvement of communication and quality control of educational and training activities.

Visual impairment is the condition of blindness or low vision that cannot be reduced with surgery, drug treatments or with the use of conventional lenses (Unione Italiana, 2017). The development of the legislation and the difficulty of defining the medicolegal evaluation of low vision in particular, as described above, suggests the complexity of the topic. The pathologies that cause low vision are as many as the number of functional relapses that can affect an individual throughout the life cycle.

In this work, attention is paid to visual impairment as total blindness, so it is interesting to make a brief reflection on how the image of the blind person has evolved over time. Historically, the most common prejudices around the blind are basically two: the one who necessarily wants them unhappy and the one who attributes them exceptional and clairvoyant qualities (Accorsini, 1988, p. 30). They are two sides of the same coin that arise from the dismay that visual impairment generates in peoples. The Tiresias model of Homer's Iliad exorcises the drama of the sensory deficit through the blind man's conquest of superhuman abilities inaccessible to the sighted. The pietistic approach, for its part, has found space in the most varied philanthropic works that have nourished themselves with the image of the "poor blind man".

History can teach us to recognize the paths already taken to identify the mistakes made and avoid them with the aim achieve full integration by blind people.

\section{The evolutionary implications related to} visual impairment at an early age

(characteristics and critical aspects of a child aged 0-3 years with blindness)

The blind child is totally deprived of the visual capacity intended as active brain function. Congenital blindness characterizes the development of the child and can lead to disabling side effects with respect to the psycho-sensorial, psycho-motor functions, the representation activity and the structuring of affective life (Ceppi, 1981, p. 63).

The studies conducted on the development of the blind child to which reference is made, which are 
considered to be the most authoritative in both the typhlological and psychological specialist fields, start from Piaget's theories which constitute a fundamental reference both scientifically and conceptually (Mazzeo, 1988, p. 24).

One of the most worrying aspects that characterizes the blind person is the inertia to action which is mainly caused by the narrowing of the field of perceptions. The small child is not induced to move to reach the silent objects that surround him because they simply do not exist for him (Accorsini, 1988, p. 32). A blind child is enticed to move on the thrust of mainly sonorous and tactile stimuli being the auditory and tactile perceptions those for him endowed with meaning. The eyes have the possibility of embracing in a single perceptual unit the whole of a space and of what it contains, objects and people through the specific syncretic quality of the sense of sight. Lack of sight requires the use of the other senses to decode, understand and enter into relationship with space, people and objects. The sense of hearing does not return complete information on the environment and that of touch has analytical - sequential characteristics that characterize the ways and times of the knowledge process. A more detailed discussion on the characteristics of the senses will be addressed in the second chapter of this work.

Knowledge is given by the interaction between the subject and the object of knowledge that is substantiated in the action, therefore the deprivation or reduction of the action can be considered the main cause of the developmental delays of the blind child (Mazzeo, 1988, p. 25). As observed by Piaget, there is a complementarity between perception and movement in that they are connected and found the distinction between simple perception and perceptual activity. Typhlologist Mazzeo observed that

"It is the active experiences as a whole that inform the subject about the characteristics of the object" (Mazzeo, 1988, p. 27).

The interaction with the object by the blind child requires information that can refer to the sensory systems and perceptual modalities that the child has available. Their activation and the habit of their use is not spontaneous and even if it becomes necessary, in the first years of life and not only, it requires mediation by the adult. Achieving an adequate organization of information and a satisfactory quality and quantity of the different aspects of knowledge requires time and a greater use of energy by the child than the sighted peers (Ceppi, 1981, p. 69).

If we consider need the engine of human action as described by Piaget (Piaget, 2000, p. 14), to encourage movement in the blind child, it is necessary to create a need in him. A need that does not exist in him and that when it is realized creates a state of imbalance. The stimulation by the adult towards the blind child must necessarily provide for the recovery of the balance and that it has to be more stable than that of the state in which it was previously. Starting from the earliest moments of the blind child's life, he must be supported in exploration and invited to movement because, through a continuous process, he will be able, like the sighted, to ensure the progressive conquest of his skills and understanding of the world as described by Piaget,

"[...] the mind therefore performs the same function, which is to incorporate the universe to itself, but the structure of this assimilation varies, that is, the subsequent forms of incorporation vary, from perception and movement to higher operations" (Piaget, 2000, p. 16).

Visual function is of enormous importance in the dyadic relationship between mother and baby and the lack of responsiveness on the part of the baby can cause a huge sense of frustration in the mother (Lanners, 2000, p. 20). The sighted child responds immediately to the visual stimulus (Greenspan, 1992, p. 33) deriving from the mother's face and from the first objects that are proposed to him at a distance of 30 centimeters from the eyes. The blind child appears more quiet in the first weeks of life and can show, even early, a bright smile (as defined by Giancarlo Accorsini) in response to the mother's voice and care practices. In the first year of life, the child's selective auditory ability will allow him to recognize his family and the strangers perfectly (Accorsini, 1988, p. 33). What explained above must be understood by parents, but also by anyone who wants to enter into a relationship with a blind child; the reciprocity of looks has a substantial meaning in communication between the sighted. The eyes say a lot and it is precisely in looking at each 
other that peoples learn the mimic expressions that enrich with meaning what they say and listen with words. This competence in the congenital blind child is generally lacking or poor, but can be supported through verbal and affective references. In communication with a blind child we will often see him keep his head bowed; keeping your head up to pay attention to the interlocutor has no meaning for those who do not see and is basically a useless effort. The acquisition of this competence has a more social than functional value for the blind child because an erect head posture is explained in a dimension of the relationship assisted by sight, but not if attention is focused on hearing.

Lack of vision has an impact on the child's ability to self-regulate and manage frustration and these characteristics are strongly influenced by the characteristics of the context and the relational ones in which he lives. In fact, a context capable of adapting to the perceptual needs of the child takes on the role of facilitator in the various moments of the child's growth (Mazzeo, 1988, p. 60). The environmental information that may appear to him from time to time disordered, overabundant or too poor must be reordered through preventive work and a relational and dialogic process.

The view allows a control over the environment that the other senses do not have and its anticipatory power protects man from being passively affected by the effects deriving from the action of the external environment. These effects are very significant and often give rise to peculiar behaviors in blind children that must be interpreted correctly: for example, the barking of a dog can generate reactions in the blind child for head protection or abrupt halt in the walking that may appear to us disproportionate if considered in the perspective of a sighted person.

From the studies of the psychologist Yvette Hatwell published in the show that the deprivation of sight entails a disturbance on the notion of space which appears in the completed form in the blind children only towards the ten years, while in the sighted towards the four, five years, confirming the intuitions that the typhlologist Augusto Romagnoli had expressed in his works of the first half of ' 900 (Mazzeo, 1988, p. 61).
Language, on the other hand, and verbal performances appear for the blind and sighted at the same age and as described in the contribution of Yvette Hatwell play a fundamental role in the progress on the concrete sector and of classification (Mazzeo, 1988, p. 53). A very recent study, carried out with the use of multimodal magnetic resonance imaging, has linked these two aspects by showing how the brain of a person born blind or who became such prematurely, readjusts regardless of the lack of vision. The plastic qualities of the brain allow a modification of its structures to guarantee the organism the best possible adaptation to the environment. In essence, it appears that there is an increase in connectivity in blind people in the areas involved in language processing compared to sighted people, while there is less connectivity in the somatosensory-motor areas of blind people involved in research compared to the control group (Bawer, 2017).

Language for the blind child has enormous relational importance and is an instrument of knowledge therefore it must be the object of care by adults so that it is built around experience. The risk that the blind child runs is that of acquiring an extraordinary verbosity, but devoid of content, this phenomenon is called verbalism. The problem is semantic in nature and appears in blind children, since the correlation between word and meaning is not supported by visual experience (Brambring, 2004, p. 304). We should carefully study the peculiarities of language development in the blind child on the discourse on the substitute function of the senses.

A child with congenital blindness can report neurological damage, especially in cases of premature birth, not to be detected in the first periods of life. The circumstance of multiple disability can therefore be ascertained later and can occur throughout the life span from to years of age and beyond (Brambring, 2004, p. 51). Personal experience has shown that a timely intervention that takes place through the collaboration between specialists, educators and family in team work is even more important in such circumstances since it allows to:

- prevent the advancement of hypotheses not supported by diagnostic data and medical opinions; 
- to underestimate significant elements that appear in the child's development observable in different contexts and that need to be subjected to the evaluation of an adequate team;

- avoid incorrect interpretations of behaviors that are part of the normal development of the child with congenital blindness, considering them pathological;

- contain feelings of unease, helplessness and professional inability;

- to enhance the different professional skills while respecting their area of intervention by building hypertext contexts that allow dialogue and discussion.

In conclusion, we can always consider the valid suggestion of Mario Mazzeo who already in the eighties urged in this sense:

"An adequate compensatory enhancement response initiated during the first year of the blind child's life could allow an even more coordinated and accommodated tactile - kinaesthetic - acoustic adaptation to the characteristics of the surrounding reality and thus favor a more differentiated and harmonious emotional experience" (Mazzeo, 1988, p. 67).

\section{The role of the family}

Meeting a child means meeting his family (Lanners, 2000, p. 13). The survival of the newborn depends on the adult figure that takes care of him, a figure that by convention we identify with the mother, but which can be covered by others, family and / or non-family members.

By nature, the infant is totally dependent on the reference adult with whom he establishes a fundamental link for his survival and development. The maternal-filial bond has been studied by many ethologists and psychologists and represents the evolutionary bond that par excellence allows humans to grow, to adapt to the environment and to deal with the world through the first social relationships (Tartabini, 2012, P. 67). John Bowlby provided the best-known study on the link between the motherchild dyad and the Attachment Theory which demonstrates the value that this link has in the emotional and affective health of the human being. The emotional roots of man are rooted in the bond with the mother and this bond serves as a model for the individual's future relationships. The quality of attachment affects the emotional security of the individual and the construction of the self and determines the level of self-esteem and the perception of self-efficacy (Carbone, 2011, p. 142). A secure attachment allows the child to test himself, to engage in an ever wider exploration of the world and to experience natural detachment from the mother in a fluid and confident progression free of anxieties or fears.

The family, therefore, is the first context of socialization and guarantees the physical and psychological growth of the child. The role of parents is crucial because the parental style has a profound influence on the social development and the socialization path of the individual. The methods of care and the educational style are influenced by the beliefs and values of the parents, the characteristics of the child, as well as the parents, and the socio-cultural context. Systems theory (Carbone, 2011, p. 167) describes the family as a dynamic entity by nature given by the result of the characteristics of its components and the relationships that are established between them; but it is also the result of the relationships that each member of the family has in other social subsets and of the experiences that each member lives outside the family. So, the family is the first context in which the child learns about social reality. Charles Cooley defined the family primary group for its dual function in building deep emotional bonds and for the fundamental role it plays in the socialization of the child (Besozzi, 2016, p. 203).

The family is a group in itself, but it is also a social institution with a precise legal position recognized starting from the Italian Constitution in the Art. 29. 30 and 31 (Gazzetta Ufficiale, 1947). Therefore, the role of the family assumes multiple aspects that are articulate in the different areas of the child's life and are related to its internal functioning, but also deriving from the relationships that its members have with the external environment.

The notion of "ecological environment" proposed by Bronfenbrenner interprets human life immersed in different systems, distant and close, arranged in a concentric structure. Each system is influenced in a 
continuous exchange that affects the individual and consequently the development of the child.

The path taken so far leads us to consider with greater attention the value of the first direct experiences of the child and his family with specialized operators and educators. The welcoming task that the educator, like the specialized operator, is required to carry out is delicate since it requires the ability to observe and respect (Moletto, 2013, p. 35). The birth of a disabled child has repercussions on the mother, the parental couple, the family and her extrafamily relationships. The first studies on the families of the disabled date back to the fifties of the last century and many support the close connection between disability and family pathology; (Zanobini, 2016, p. 21) Parmenter's study is particularly interesting, showing how the result of these studies starts from an underlying prejudice connected to the concept of normality:

"The language of normality sends the implicit message that there is something wrong with these people." (Zanobini, 2016, p. 22).

What is not "normal" is "different", because it does not respect a stereotypically socially shared canon and therefore indistinctly both the child and the family are considered pathological. Anyone is confronted with the danger of looking at the family only and exclusively in these terms, an aspect that in the professions that take place in contact with a disabled person and his family, must be problematized with a critical attitude (Nobile, 2014, p. 11).

The indications of the WHO and the conceptual approach of the ICF are an example of the political will to take a social perspective towards disability and therefore also towards family contexts.

"Taking a different perspective means first of all thinking of disability as a concrete possibility in the life of each of us [...] it also means realizing that impairment and the consequent disability are only one aspect of the life of people and do not coincide with it, so the presence of a disabled member is only a part, however central in some moments, in the life of families" (Zanobini, 2006, p. 23).

When a disabled child is born, the mother, the father and the family find themselves in a situation they had not foreseen and had not desired. The discussion conducted so far does not want to deny the condition of suffering to which a family is exposed in having a disabled child, nor the infinite internal psychological implications that can result from it. The properly psychological or psychopathological aspects concern other areas of study and involve competent specialists in other subjects.

We have chosen to focus attention on an ecological-relational and social perspective since it is the one in which the educator is called to exercise the skills he possesses.

The stereotyped representations of the families of a disabled child can be replaced if we start from an approach that considers parents:

"As knowledge-producing subjects, as a source of knowledge and as special experts for their children" (Moletto, 2013, p. 9).

The experiences of parents and family with their child are very useful to professionals who take care of the child as Ferrière wrote:

"Parents are the primary agents of their children's education. The teachers are the auxiliaries of this work." (Moletto, 2013, p. 17).

In conclusion, the awareness that the cultural roots of the child reside within his family and that his emotional stability deepens in the relationship with the mother figure, allows us to credit the parental figures as competent in order to build an alliance and a pact educational based on everyone's knowledge (Moletto, 2013, p. 39).

\section{Educational contexts}

The word context is found in the Latin term contextus which in the form of noun means weaving, orderly bond. Contextus derives from the term contexo which means to weave together, to weave (Castiglioni, 1994, p. 200) and is formed by the prefix con- and the word text which in turn means fabric (Castiglioni, 1994, p. 1058). Therefore, in the present work, it refers to spun weaving through a logical, but also practical process, that is, proper to relational doing, which holds several elements together in an orderly bond.

An educational context is interwoven with educational intentions that find their dimension in the very meaning of the term. The term educating etymologically means bringing out 
(Castiglioni, 1994, p. 299) what translates, within an educational context, into educational practices aimed at leading the child towards his personal realization, as described by Sergio Tramma in his contribution:

"The term education refers to all practices that influence the way of being of the individual, whether intentional or not, considered in their material, technical, prescriptive, ideological, value and teleological implications, understood in their translation and implementation" (Tramma, 2010, p. 14).

The educational context is therefore built into a plot in which educational practices and people, actors of the educational event, are constantly evolving within a dialogic-relational exchange. In our sense, the context is the place of learning located in close connection with the material, human and symbolic resources used for the purpose of educating and developing relationships that involve, in a reciprocal way, educators and who is being educated. The first educational context in which a child relates, as mentioned, is the family and generally the nest represents the second educational context. The nursery is the first institution with a declared formal educational intention, with which the child generally comes across.

The birth of a disabled child leads parents to initially follow an itinerary that winds around the child's pathology. Parents spend themselves looking for the reasons and possible solutions to their child's disability, they are focused on the medical-health and rehabilitation aspects. These first attention of parents towards their child are understandable and must be respected, but at the same time considered by professionals who can support parents in finding a different relationship with their child. Parents risk forgetting

"The simple evidence that the disabled child is, above all, a child, who needs care, parental attention and educational approaches just the same as all other infants" (Caldin, 2006, p. 19).

The blind child arrives early in non-formal educational contexts (Tramma, 2010, p. 26), external to the family, and such experiences generally precede entry to the nursery. These contexts can be different, from the therapeutic cabinets to the rooms of the activities of special professionals, the territorial rehabilitation services and / or the private rehabilitation services, where adults meet in virtue of the problems of the child. In interacting with the child, the special professional lives an experience of relationship and establishes the relationship of trust that makes intervention possible; moreover, over time the relationship grows and develops both with the child and with the parents. These relationships, rich in data of mutual knowledge, are resources within the separate special context, but also useful in contexts open to all. The experiences of special professionals with the child and his family, in fact, could have a resonance within the educational contexts open to all and carry out a mediating function between the new social experiences of the blind child and education professionals (Canevaro, 2000, p. 3).

The family, special professionals and education professionals together can cooperate to achieve what Edda Ducci says about educating: "helping the other to become that single individual who only he can be. To make the other discover that vocation that is his alone. Help him find and walk his own unique path. To find the meaning of one's own life, that sense that says its uniqueness" (Costa, 2014, p. 38).

The cooperation between the adults involved in the life of a blind child is aimed at the educational task of making the child capable of making choices, whatever the condition he is in. The different contexts can be intertwined again to become success generators, amplifying one's action and the child's own action, to create new contexts in which mutual growth takes place.

"Equal exchanges between parents and experts gain in quality and creativity, enriching themselves in the recognized reciprocity in connections and in the exchange of practical and theoretical knowledge. The climate of availability and humility allows us to undo prejudices and wrong representations" (Moletto, 2013, p. 47).

Technicality generates isolation and separation, it is sterile and an end in itself. The figure of Freire's oppressor finds life in contexts incapable of dialogue, between people who do not mutually recognize equal human and professional dignity. 
"The objective situation of domination is in itself a separatist situation" (Freire, 2002, p. 171).

A primary objective in working with a blind child's family is to support parenting, transfer a perception of competence to parents and accompany them on their individual path so that they are not new oppressed, but recognize each other

"as beings transforming reality, which before was something mysterious to them; transformers through their creative work" (Freire, 2002, p. 174).

The dialogue and attention to the social implications that educational agencies play, in the role of professionals who are part of it, must also take into account their preventive value. Studies on child abuse include the presence of disabilities at the birth of the child among the risk factors for child maltreatment and, to this factor, others are associated, including social isolation, the quality of socialization and the quality of social support interventions. The risk factors listed are part of the reflection of this work and are an element to further support and validate the above (Caffo, 2004, p. 101).

In conclusion, what Frederc Jèsu wrote about coeducation can represent a point of reflection for all professionals:

"... every professional is also a parent, or at least has parents, for this reason he discovered parenting by observing and experiencing, in the true sense of the term, his parents parenting and built his own, by experimenting with his responsibilities towards children. Every childhood or family professional necessarily has a personal experience and not just professional knowledge of parenting. This experience makes him aware that even though nobody is totally ignorant in this field, nobody is totally expert. Everyone, professional or parent who is, knows, can do, and can do something different and complementary to what the other knows, can do and and is able to do" (Moletto, 2004, p. 47).

\section{REFERENCES}

Accorsini, G. (1988). Il bambino cieco nella scuola dell'infanzia e dell'obbligo, Collana MedicoPsicoPedagogica directed by G. Bollea, Armando Editore, Roma 1988, pp. 30 - 31.

Accorsini, G. (1988). Il bambino cieco nella scuola dell'infanzia $e$ dell'obbligo,Collana MedicoPsicoPedagogica directed by G. Bollea, Armando Editore, Roma, p. 32.
Accorsini, G. (1988). Il bambino cieco nella scuola dell'infanzia $e$ dell'obbligo, Collana MedicoPsicoPedagogica directed by da G. BOLLEA, Armando Editore, Roma 1988, p. 33.

Accorsini Giancarlo. (1988). Il bambino cieco nella scuola dell'infanzia $e$ dell'obbligo, Collana MedicoPsicoPedagogica diretta da Giovanni Bollea, Armando Editore, Roma 1988, pp. 32-35.

Agenzia Internazionale per la Prevenzione della Cecità (International Agency fo the Prevention of Blindness, IAPB Italia onlus). (2007). http://www.iapb.it/retinopatiadel-prematuro-rop Page published on December 3rd, 2007, last actualization: September 7th, 2016, last scientific revision Octuber 25th, 2012, accessed 26.10.2017.

Agenzia Internazionale per la Prevenzione della Cecità (International Agency fo the Prevention of Blindness, IAPB Italia onlus), (2017). http://www.iapb.it/polonazionale/ipovisione-eriabilitazione-visiva page published on 11.12.2010, last actualization 24.10.2017, accessed 26.10.2017.

Agenzia Internazionale per la Prevenzione della Cecità (Internationa Agency for the Prevention of Blindness IAPB Italia onlus), (2017). http://www.iapb.it/malattie-oculari accessed 01.11.2017

Bawer, C.M., Hirsch, G.V., Zajac L., Koo B.B., Collignon. O., Merabet, L.B. (2017). Come la cecità neonatale trasforma la corteccia cerebrale. L'imaging multimodale con risonanza magnetica rivela cambiamenti strutturali $e$ funzionali della connettività neuronale nei ciechi assoluti precoci. Oftalmologia Sociale. Rivista di Sanità Pubblica. Anno XL (2017), N. 3.

Besozzi, E. (2016). Società, cultura, educazione, Carocci Editore, Roma 2016, pp. 203-206.

Bianchi, P.E. (2009). Il Cerebral Visual Impairment (CVI) in "CHILD DEVELOPMENT \& DISABILITIES - SAGGI" 1/2009, pp. 9-19.

Brambring, M. (2004). Lo sviluppo nei bambini non vedenti. Osservazione e intervento precoce, Franco Angeli, Milano 2004, p. 304-305.

Brambring, M. (2004). Lo sviluppo nei bambini non vedenti. Osservazione e intervento precoce, Franco Angeli, Milano 2004, p. 51.

Brambring, M. (1999). Entwicklungsbeobachtung undförderung blinder Klein - und Vorschulkinder, Edition Bentheim, Würzburg; eng. translation The blind child development. Observation and early intervention. Franco Angeli, Milano 2004, p.13.

Brambring, M. (1999). Entwicklungsbeobachtung undförderung blinder Klein - und Vorschulkinder, Edition Bentheim, Würzburg 1999; eng. translation The blind child development. Observation and early intervention. Franco Angeli, Milano 2004, p.13.

Canevaro, M.A. (2016). Le logiche del confine e del sentiero. Una pedagogia dell'inclusione (per tutti, disabili inclusi). Erickson, Trento, p. 113.

Brambring, M. (1999). Entwicklungsbeobachtung undförderung blinder Klein - und Vorschulkinder, Edition Bentheim, Würzburg; English translation The blind child 
development. Observation and early intervention. Franco Angeli, Milano 2004, p.13.

Brambring, M. (1999). Entwicklungsbeobachtung undförderung blinder Klein - und Vorschulkinder, Edition Bentheim, Würzburg; English translation The blind child development. Observation and early intervention. Franco Angeli, Milano 2004, p.13.

Buono, S., Zagaria, T. (2003). ICF - Classificazione internazionale del funzionamento, della disabilità e della salute, Ciclo Evolutivo e Disabilità (Life Span and Disability), 6,(1), 2003, 126 - 127.

Buono, S., Zagaria, T. (2003). ICF - Classificazione internazionale del funzionamento, della disabilità e della salute, Ciclo Evolutivo e Disabilità (Life Span and Disability), 6,(1), 2003, pp. 124-125.

Buono, S., Zagaria, T. (2003). ICF - Classificazione internazionale del funzionamento, della disabilità e della salute, Ciclo Evolutivo e Disabilità (Life Span and Disability). 6,(1), 2003, 126 - 130.

Buono, S., Zagaria, T. (2003). ICF - Classificazione internazionale del funzionamento, della disabilità e della salute, Ciclo Evolutivo e Disabilità (Life Span and Disability). 6,(1), 2003, 126 - 130.

Caffo, E., Camerini, G.B., Florit, G. (2004). Criteri di valutazione nell'abuso all'infanzia. Elementi clinici e forensi. Mcgraw-hill, Milano 2004, p.101 - 112.

Caldin. R. (Ed.). (2006). Percorsi educativi nella disabilità visiva. Identità, famiglia e integrazione scolastica e sociale, Erickson, Trento 2006, p. 19.

Canevaro, A. (2016). Le logiche del confine e del sentiero. Una pedagogia dell'inclusione (per tutti, disabili inclusi), Erickson, Trento 2016, p. 19.

Canevaro, A. (2016). Le logiche del confine e del sentiero. Una pedagogia dell'inclusione (per tutti, disabili inclusi), Erickson, Trento 2016, pp. 121 - 122.

Canevaro, A. (2000). Pedagogia speciale. La riduzione dell'handicap. Bruno Mondadori, Milano 2000, pp. 3-10.

Castiglioni, L., Mariotti, S. (1994). IL Vocabolario della lingua latina, Loescher Editore, Torino, Fotocomposizione: Elios - Trento, Stampa: OFSA - Casarile, Milano 1994, pp. 200.

Castiglioni, L., Mariotti, S. (1994). IL Vocabolario della lingua latina, Loescher Editore, Torino, Fotocomposizione: Elios - Trento, Stampa: OFSA - Casarile, Milano 1994, pp. 1058.

Castiglioni, L., Mariotti, S. (1994). IL Vocabolario della lingua latina, Loescher Editore, Torino, Fotocomposizione: Elios - Trento, Stampa: OFSA - Casarile, Milano 1994, pp. 299.

Carbone, R. (2011). Lezioni di psicologia dello sviluppo, Uni Nova, Parma 2011, pp. 142-156.

Carbone, R. (2011). Lezioni di psicologia dello sviluppo, Uni Nova, Parma 2011, pp 167.

Ceppi, E. (1981). I minorati della vista. Storia e metodi educativi, Armando editore, Roma, p. 64.

Ceppi E. (1981). I minorati della vista. Storia e metodi educativi. Armando editore, Roma, p. 65.

Ceppi, E. (1981). I minorati della vista. Storia e metodi educativi. Armando editore, Roma 1981, pp. 63-65.
Ceppi, E. (1981). I minorati della vista. Storia e metodi educativi. Armando editore, Roma 1981, pp. 69-72.

Costa, C. (Ed.). (2014). Per una filosofia dell'educazione. La riflessione di Edda Ducci attraverso i suoi scritti. "Teoria e storia dell'educazione", Collana diretta da Francesco Mattei, Anicia, Roma 2014, p. 38.

Cruciani, F., Grasso, M.Lo, Esposito, M.C., Mazzeo, L. (2005). Oftalmologia Sociale, Classificazione dell'ipovisione International, Symposium on Low Vision Rehabilitation and Visual Ability, on 10th-12th March 2005, Year XXIX N. 2 April - June 2006, p. 14 - 16.

Cruciani, F., Grasso, M.Lo, Esposito, M.C., Mazzeo, L. (2005). Oftalmologia Sociale, Classificazione dell'ipovisione International, Symposium on Low Vision Rehabilitation and Visual Ability, on 10th-12th March 2005, Year XXIX N. 2 April - June 2006, p. 17.

Centofanti, M., Stirpe, M. (2017). Cause di cecità e nuove strategie terapeutiche, http://www.treccani.it/enciclopedia/cause-di-cecita-enuove-strategie-terapeutiche_\%28XXI-Secolo\%29/2010, accessed 25.10.2017.

Debray, R., Belot, R.A. (2009). Psicosomatica della prima infanzia, Casa Editrice Astrolabio - Ubaldini Editore, Roma, p. 31.

Freire, Figli di Paulo. (2002). La pedagogia degli oppressi, Edizione Italiana edts. L. Bimbi, EGA Edizioni, Torino 2002, p. 171.

Freire, Figli di Paulo. (2002). La pedagogia degli oppressi, Edizione Italiana edts. L. Bimbi, EGA Edizioni, Torino 2002, p. 174.

Gatty, J. (2010). Quatre réflexions sur l'éducation, Presses Universitaires de France, Paris 1993; Italian translation Finalità dell'educazione. Educazione e libertà, Anicia, Roma, pp. 28 - 32.

Gatty, J. (2010). Quatre réflexions sur l'éducation, Presses Universitaires de France, Paris 1993; Italian translation Finalità dell'educazione. Educazione e libertà, Anicia, Roma, pp. 36 - 39.

Gazzetta Ufficiale. (1947) 27.12.47, accessed il 27.10.2017. http://www.gazzettaufficiale.it/dettaglio/codici/costituzione

Gazzetta Ufficiale. (1992). Legge-quadro per l'assistenza, l'integrazione sociale e i diritti delle persone handicappate. GU Serie Generale n.39 del 17-02-1992 - Suppl. Ordinario n. 30) Date of law enforcement: 18-2-1992 http://www.gazzettaufficiale.it/eli/id/1992/02/17/092G010 8/sg, accessed 01.11.17.

Gazzetta ufficiale. (1992). Law February 5th, 1992, n. 104, Legge-quadro per l'assistenza, l'integrazione sociale e i diritti delle persone handicappate. (Framework law for the assistance, social integration ans rights of handicapped persons)(GU Serie Generale n.39 del 17-02-1992 - Suppl. Ordinario n. 30), Date of law enforcement: 18-2-1992, http://www.gazzettaufficiale.it/eli/id/1992/02/17/092G010 8/sg, accessed 26.10.2017.

Gazzetta Ufficiale. (1992). Art. 1, Law February 5th, 1992, n. 104 Legge-quadro per l'assistenza, l'integrazione sociale e $i$ diritti delle persone handicappate. (Framework law for 
the assistance, social integration ans rights of handicapped persons, GU Serie Generale n.39 del 17-02-1992 - Suppl. Ordinario n. 30) Date of law enforcement: 18-2-1992, accessed

26.10.2017. http://www.gazzettaufficiale.it/eli/id/1992/02/17/092G010 $8 / \mathrm{sg}$

Gazzetta Ufficiale. (2017). Decreto legislativo 13 aprile 2017, n. 66 Norme per la promozione dell'inclusione scolastica degli studenti con disabilita', following art. 1, paragraph 180 e 181, letter c), of the law July 3rd, 2015, n. 107. (17G00074) GU General Series n.112, of 16-05-2017 Suppl. Ordinario n. 23 Date of law enforcement: 31.05.2017, $\quad$ accessed 27.11 .17 . http://www.gazzettaufficiale.it/eli/id/2017/05/16/17G0007 $4 / \mathrm{sg}$

Gazzetta Ufficiale Legge. (2015). July 13th, 2015, n. 107 Riforma del sistema nazionale di istruzione e formazione e delega per il riordino delle disposizioni legislative vigenti, (15G00122) (GU Serie Generale n.162 del 15-07-2015), Date of law enforcement: 16/07/2015, accessed 27.11.17. http://www.gazzettaufficiale.it/eli/id/2015/07/15/15G0012 $2 / \mathrm{sg}$.

Gazzetta Ufficiale. (2017). Art. 5, law decree April 13th, 2017, n. 66 Norme per la promozione dell'inclusione scolastica degli studenti con disabilita', following art. 1, paragrphs 180 and 181, letter c), from law July 13th, 2015, n. 107. (17G00074) GU General Series n.112, del 16-05-2017 Suppl. Ordinario n. 23, Date of law enforcement: 31.05.2017, accessed 27.11.17. http://www.gazzettaufficiale.it/eli/id/2017/05/16/17G0007 $4 / \mathrm{sg}$.

Glossario ISTAT. (2013). Condizioni di salute e ricorso ai servizi sanitari, http://www.istat.it/it/files/2014/12/Glossario_salute2.pdf?title $=\mathrm{La}+$ salute $+\mathrm{e}+\mathrm{il}+$ ricorso + ai + servizi + sanitari + +29\%2Fdic\%2F2014+-+Glossario.pdf 2013, accessed 27.10.2017.

Greenspan, S., Thorndike, N. (1992). Le prime sensazioni. Come pianificare la crescita emozionale del bambino dalla nascita fino ai quattro anni, Sovera Multimedia S.r.l., Roma, pp. 21-24.

Greenspan, S., Greenspan, T.N. (1992). Le prime sensazioni. Come pianificare la crescita emozionale del bambino dalla nascita fino ai quattro anni, Sovera multimedia S.r.1., Roma 1992, p. 33.

Hoyuelos A. (2014). Il soggetto Bambino. l'etica pedagogica di Loris Malaguzzi, Edizioni Junior - Spaggiari Edizioni S.r.1., Parma, pp. $25-26$

International Agency fo the Prevention of Blindness (IAPB Italia onlus).

http://www.iapb.it/polonazionale/ipovisione-eriabilitazione-visiva page published 11.12.2010, last actualization 24.10.2017, accessed 26.10.2017.

International Agency fo the Prevention of Blindness (IAPB Italia onlus) (2012). http://www.iapb.it/acuita-visiva page published on December, 12th, 2012, last actualization:
September 7th, 2016, last scientific revision: 12th December 2012, accessed 26.10.2017.

Lanners, J., Salvo, R. (2000). Un bambino da incontrare. Per mamma e papà... quando nasce un bambino con problemi visivi. Fondazione Robert Hollmann, Cannero RivieraRiviera (VB) 2000, pp.20-21.

Lanners, J., Salvo, R. (2000). Un bambino da incontrare - Per mamma e papà... quando nasce un bambino con problemi visivi. Fondazione Robert Hollmann, Cannero Riviera 2000, pp. 13-21.

Law April 3rd, (2001). n. 138 published in the Gazzetta Ufficiale (Official Gazette) n. 93 of April 21st, 2001 http://www.gazzettaufficiale.it/atto/serie_generale/caricaD ettaglioAtto/originario; jsessionid $=\mathrm{X}+7 \mathrm{JDJWa} 0+\mathrm{KP} 7 \mathrm{aVc}$ X2uiRA_ntc-as3guri2a?atto.dataPubblicazioneGazzetta $=2001-04-$ 21\&atto.codiceRedazionale $=001 \mathrm{G} 0193$ \&elenco30giorni $=$ false 21.04.2001, accessed 27.10.2017.

Law, Aprile 3rd, (2001). n. 138 published in the Gazzetta Ufficiale (Official Gazette) n. 93 of Aprile 21sr, 2001 http://www.gazzettaufficiale.it/atto/serie_generale/caricaD ettaglioAtto/originario;jsessionid $=\mathrm{X}+7 \mathrm{JDJWa} 0+\mathrm{KP} 7 \mathrm{aVc}$ X2uiRA_.ntc-as3guri2a?atto.dataPubblicazioneGazzetta $=2001-04-$ 21\&atto.codice Redazionale $=001 \mathrm{G} 0193$ \&elenco30giorni $=$ false 21.04.2001, accessed 27.10.2017.

Mazzeo, M. (1988). Il bambino cieco. Introduzione allo sviluppo cognitivo. Anicia, Roma 1988, p 24 - 29

Mazzeo, M. (1988). Il bambino cieco. Introduzione allo sviluppo cognitivo, Anicia, Roma 1988, pp. 25-27.

Mazzeo, M. (1988). Il bambino cieco. Introduzione allo sviluppo cognitivo, Anicia, Roma 1988, p.27.

Mazzeo, M. (1988). Il bambino cieco. Introduzione allo sviluppo cognitivo. Anicia, Roma 1988, pp. 60-61.

Mazzeo, M. (1988). Il bambino cieco. Introduzione allo sviluppo cognitivo, Anicia, Roma 1988, p. 61.

Mazzeo, M. (1988). Il bambino cieco. Introduzione allo sviluppo cognitivo, Anicia, Roma 1988, p. 53.

Mazzeo M. (1988). Il bambino cieco. Introduzione allo sviluppo cognitivo, Anicia, Roma 1988, p. 67.

Menichini, I., Treccani. http://www.treccani.it/enciclopedia/disabilita_\%28IlLibro-dell\%27Anno\%29/ 2003, accessed 27.10.2017.

Ministero della Salute (Minsitry of Health). (2017). Giornata mondiale della vista 2017 (World sight day), http://www.salute.gov.it/portale/news/p3_2_1_1_1.jsp?lin gua $=$ italiano $\&$ menu $=$ notizie $\& p=$ dalministero $\& \mathrm{id}=3113$ date of publication and last actualization 12.10.2017, accessed 27.10.2017.

Moletto, A., Zucchi, R. (2004). La metodologia pedagogia dei genitori. Maggioli Ed., Rimini 2013, cite by Frederic Jèsu 2004 at p. 47.

Moletto, A., Zucchi, R. (2013). La metodologia pedagogia dei genitori, Maggioli Editore, Rimini 2013, p. 35-36.

Moletto, A., Zucchi, R. (2013). La metodologia pedagogia dei genitori. Maggioli Ed., Rimini 2013, p.9. 
Moletto, A., Zucchi, R. (2013). La metodologia pedagogia dei genitori. Maggioli Ed., Rimini 2013, p.17.

Moletto, A., Zucchi, R. (2013). La metodologia pedagogia dei genitori. Maggioli Ed., Rimini 2013, pp. 39-47.

Moletto, A., Zucchi, R. (2013). La metodologia pedagogia dei genitori. Maggioli Ed., Rimini 2013, p. 47.

Nobile, A. (2014). Il pregiudizio. Natura, fonti, modalità di risoluzione, Ed. La scuola, Brescia 2014, pp. 11-19.

Normattiva, portale della legge vigente. (1978). (Actual in force law portal) Accertamenti e trattamenti sanitari volontari e obbligatori. GU n.133 del 16-5-1978, Date of law enforcement: 17.05.1978. Disposition in the art 1, 2, 3, 4, $5,6,7,8$, e 9 of the present law are enforced until the enforcement of the institutve law of the national health service. http://www.normattiva.it/urires/N2Ls?urn:nir:stato:legge:1978-05-13;180, accessed 01.11.17; also see http://www.salute.gov.it/imgs/C_17_normativa_888_alleg ato.pdf. accessed 01.11.17.

Normattiva, portale della legge vigente. (1977). (Actual in force law portal) Norme sulla valutazione degli alunni $e$ sull'abolizione degli esami di riparazione nonche' altre norme di modifica dell'ordinamento scolastico. GU n.224 on 18-8-1977 http://www.normattiva.it/urires/N2Ls?urn:nir:stato:legge:1977-05-13;517 Art. 10, accessed 01.11.17.

Piaget J. (2000). Lo sviluppo mentale del bambino e altri studi di psicologia. Piccola Biblioteca Einaudi, Torino 2000, pp.14-15.

Piaget, J. (2000). Lo sviluppo mentale del bambino e altri studi di psicologia. Piccola Biblioteca Einaudi, Torino 2000, p.16.

Rop Italia, Associazione gruppo di studio per la retinopatia del pretermine (Association study group on the Rethynopaty of prematurity). (2017). Relazione stata presentata in occasione del Convegno: "ROP DALLA A ALLA Z", Bari, 25th - 26th June 2010, dr.ssa Daniela Dolcino, Direttore S.C. di Oculistica - Azienda Ospedaliera di Alessandria, accessed

http://www.ropitalia.it/wwwropitaliait.html

Sani F., Pandolfi L. (Eds.). (2013). Modelli e percorsi di tirocinio per l'Università. Conference Proceedings "Università, Tirocinio, Territorio". Pensa Multimedia Editore s.r.l., Lecce, p. 44.

Società Oftalmologica Italiana (Italian Ophthalmological Society, SOI). (2017). http://www.soiweb.com/occhiovista.php accessed 01.11.2017.

Tesio, E. (2000). (Eds.). L'uovo fuori dal cesto. Dinamiche affettive con i disabili e le loro famiglia. UTET Università, pp. $18-20$.

Tartabini, A., Giusti, F. (2006). Origine ed evoluzione del linguaggio. Scimpanzé, ominidi e uomini moderni. Liguori Editori, Napoli 2006, pp. 123-127.

Tartabini, A. (2012). Fondamenti di psicologia evoluzionistica, Liguori Editore, Napoli 2012, pp. 67-68.

Tramma, S. (2010). Pedagogia sociale. Processi Formativi e Scienze dell'Educazione, Guerini scientifica, Milano 2010, p. 14.

Tramma, S. (2010). Pedagogia sociale. Processi Formativi e Scienze dell'Educazione, Guerini scientifica, Milano 2010, p. 26.

Unione Italiana dei Ciechi e degli Ipovedenti onlus. (2017). Linee guida per la riabilitazione funzionale e visiva dell'ipovedente

https://www.uiciechi.it/documentazione/paginetematiche/i povisione.asp accessed 01.11.17.

Zanobini, M., Manetti, M., Usai, M.C. (2016). La famiglia di fronte alla disabilità. Stress, risorse e sostegni, Erickson, Gardolo (TN) 2006, pp. 21-26.

Zanobini, M., Manetti, M., Usai, M.C. (2016). La famiglia di fronte alla disabilità. Stress, risorse e sostegni, Erickson, Gardolo (TN) 2006, pp.22.

Zanobini, M., Manetti, M., Usai, M.C. (2006). La famiglia di fronte alla disabilità. Stress, risorse e sostegni, Erickson, Gardolo (TN) 2006, p. 23.

\section{СЛІПА ДИТИНА У РАННЬОМУ ВІЦІ (0-3 РОКИ) І НАВЧАЛЬНА ІНТЕРВЕНЦІЯ} Дімітріс Аргіропоулос

Кандидат педагогічних наук, Університет Парми, Парма, Італія Дана робота стикається з необхідністю початкових органічних роздумів щодо ролі виховання, щодо втручання, спрямованого на сприяння при зростанні сліпої дитини з ранніх років. Зорове відхилення має з'єднання в таких сферах як юридична, система охорони, соціальна і виховна, які спільно беруть участь при визначенні незрячої людини разом 3 індивідуальними і культурними характеристиками контекстів, в яких він знаходиться. Також, робота намагається уточнити теми, які вважаються основними для перших роздумів щодо розвитку незрячої дитини в перші роки життя. Прикметники сліпий і незрячий використовуються для визначення дитини з вродженим, повною відсутнім зором. Ці два терміни слушно змальовують характеристики дитини, що підлягають дослідженню, і будуть використовуватися як синоніми. Чоловічий рід був обраний довільно, щоб полегшити читання, але відноситься до обох статей, як до хлопчиків, так і до дівчаток.

КЛЮЧОВІ СЛОВА: Інвалідність зору, діагностика "visus", освітні втручання, сімейний і освітній контекст, активація сім'ї

\section{СЛЕПОЙ РЕБЕНОК В РАННЕМ ДЕТСТВЕ (0-3 ЛЕТ) И ОБРАЗОВАТЕЛЬНОЕ ВМЕШАТЕЛЬСТВО}

Димитрис Аргиропоулос

Кандидат педагогических наук, Университет Пармы, Парма, Италия Данная работа сталкивается с необходимостью начального органического размышления касательно роли воспитания, относительно вмешательств, направленных на содействие при росте слепого ребенка с самых ранних лет. Зрительное отклонение имеет соединения в таких сферах как юридическая, здравоохранительная, социальная и воспитательная, которые 
совместно участвуют при определении незрячего человека вместе с индивидуальными и культурными характеристиками контекстов, в которых он находится. Также, работа пытается уточнить темы, считающиеся основными для первого размышления относительно развития незрячего ребенка в первые годы жизни. Прилагательные слепой и незрячий используются для определения ребенка с врожденным, полным отсутствием зрения. Эти два термина подходяще описывают характеристики ребенка, подлежащие исследованию, и будут использоваться как синонимы. Мужской род был выбран произвольно, чтобы облегчить чтение, но относится к обоим полам, как к мальчикам, так и к девочкам.

КЛЮЧЕВЫЕ СЛОВА: Инвалидность зрения, диагностика "visus", образовательные вмешательства, семейный и образовательный контекст, активация семьи 